\title{
Effect of Filter-Press Cake on Tomato Plants Grown in Sterilized and Unsterilized Soil
}

\author{
María del C. C. Fernaindez ${ }^{1}$
}

\section{INTRODUCTION}

Filter-press cake is a waste product of the sugar industry obtained while filtering the juices prior to crystallization. This product is frequently used as manure because of its apparent beneficial effect on growth and development of plants. Yet some workers, such as Samuels and Landrau, Jr., (1) ${ }^{2}$ found that when filter-press cake was included in sugarcane experiments, in combination with commercial mixed inorganic fertilizers, no appreciable increase in yield was obtained. On the other hand, filter-press cake when applied at 10 tons per acre increased the yields of tomatoes, peppers, and taniers. Nevertheless, there was no significant effect on corn, pigeonpeas, tobacco, yams, or sweetpotatoes.

Riollano (2) reported significant increases in yield of tomatces when using 12 tons of filter-press cake plus 1,000 pounds of fertilizer 8-10-15, amounting to 20.5 percent over the treatment where fertilizer 8-10-15 was applied alone at the rate of 1,000 pounds per acre. Landrau, Jr., and Samuels (3) also reported increases in tomato yields when using 10 tons of filter-press cake per acre, but 20 tons decreased the yield.

Landrau, Jr., and Samuels (4) had low yields of sweetpotatoes when treated with filter-press cake. So did Bonnet, Lugo-López, and Rico-Ballester (5) with white beans and sweetpotatoes, but not with corn. HernándezMedina $(6,7,8)$ found that the addition of filter-press cake increased the yield of pineapple fruits, slips, and suckers significantly, in plants grown in half-drums and in the field, and Hernández-Medina, Lugo-López, and Cibes-Viadé (9) reported significant increases in yield in pineapples grown under field conditions.

The luxuriant effect on growth, development, and yield of pineapple plants, tomatoes, corn, and other crops and plant species, led to further study in order to determine whether there is some growth factor in filterpress cake, other than those to which some workers attribute the release of the minerals in the filter-press cake, or those that produce its beneficial effect on the physical properties of the soil, as indicated in the work of Lugo-López, Hernández-Medina, and Landrau, Jr., (10), and of Locsin (11).

${ }^{1}$ Associate Nutritionist, Agricultural Experiment Station, University of Puerto Rico, Río Piedras, P.R. The author wishes to express her most sincere appreciation to Mr. Adolfo Cruz-Miret, Research Assistant in Agronomy, for his personal interest in preparing the statistical analysis of this work.

${ }^{2}$ Italic numbers in parentheses refer to Literature Cited, p. 170. 
Filter-press cake undergoes a strong fermentation and micro-organisms thrive on it before and after fermentation. To eliminate the possible effect of the micro-organisms in the soil when using filter-press cake, we established an experiment in the greenhouse making use of sterilized soil and sand, compared with unsterilized soil and sand, adding 1 percent of filterpress cake, the customary quantity used in the field.

\section{EXPERIMENTAL PROCEDURE}

Tomato seedlings, variety Marglobe, were selected from a seedbed, all of nearly the same size, and were transplanted on December 11 into pots with a weighed amount of soil and sand to which 1 percent of filter-press cake was added. Three plants were grown until they were thinned down to only one plant per pot. Five treatments were applied: 1, Untreated soil + 1-percent filter-press cake; 2 , sterilized soil + 1-percent filter-press cake; 3 , sand + 1-percent filter-press cake; 4, sterilized soil; and 5, unsterilized soil. The plants were watered daily with the same amount of water.

\section{RESULTS}

The results obtained with each treatment are shown in table 1 . The plants were harvested on February 3, after being measured and weighed without the roots.

The tomato plants grown in the sterilized soil + 1-percent filter-press cake significantly weighed more at the 1-percent level than those in any of the other treatments. The plants receiving this treatment were the first to bloom (table 2).

The plants grown in sand +1 -percent filter-press cake were better at the 1-percent level than those grown in the untreated soil alone, and at the 5-percent level than those grown in the untreated soil + 1-percent filterpress cake.

\section{CONCLUSIONS}

Tomato plants grown in sterilized soil + 1-percent filter-press cake significantly weighed more than those grown in the sterilized soil alone and were also the first to bloom. While the effect of filter-press cake on the plants grown in unsterilized sand + 1-percent filter-press cake, as compared with those grown in sand alone, might be ascribed to the nutrients in the filter-press cake, it seemed the effects reported for filter-press cake on plants are disproportionate to the quantity of nitrogen and phosphorus contained. Possibly another factor may be responsible, as those grown in the sterilized soil + 1-percent of filter-press cake completely blossomed at the end of the experiment while no plant flowered when grown in the sterilized soil alone. 
Nevertheless, the plants grown in the untreated soil + 1-percent filterpress cake were low in weight, and all, except one plant, failed to flower throughout the experiment. If there is some growth substance in filterpress cake, perhaps the micro-organisms counteracted the effect of the filter-press cake on yield in this treatment, or the micro-organisms in the soil may have counteracted some other effect of some other substance beneficial in the development of the plant. This is still to be determined.

TABLE 1.-Effect of filter-press cake on tomato plants grown on sterilized vs. unsterilized soil and sand, respectively

\begin{tabular}{l|c|c}
\multicolumn{1}{c|}{ Treatment } & Average height & Average weight \\
\cline { 2 - 2 } & Inches & Grams \\
Sterilized soil + 1-percent filter-press cake & 21 & 31 \\
Unsterilized soil + 1-percent filter-press cake & 17 & 17 \\
Unsterilized sand + 1-percent filter-press cake & 21 & 25 \\
Sterilized soil & 18 & 20 \\
Sterilized sand & 11 & 10 \\
\hline
\end{tabular}

TABLE 2.-Effect of manuring with 1-percent filler-press cake on dale of flowering of tomato plants ${ }^{1}$

\begin{tabular}{|c|c|c|c|c|}
\hline Untreated soil & Sterilized soil & $\begin{array}{c}\text { Untreated } \\
\text { soil + 1-percent } \\
\text { filter-press cake }\end{array}$ & $\underset{\substack{\text { Sterilized soil }+ \text { percent filter-press } \\
\text { cake }}}{+}$ & $\begin{array}{l}\text { Sand + 1-percent } \\
\text { filter-press } \\
\text { cake }\end{array}$ \\
\hline - & 一 & & $\begin{array}{l}\text { Started to bloom } \\
\text { by Feb. } 1\end{array}$ & - \\
\hline- & $\begin{array}{l}2 \text { plants started } \\
\text { to bloom }\end{array}$ & $\begin{array}{l}1 \text { plant in } \\
\text { bloom }\end{array}$ & $\begin{array}{l}\text { All } 10 \text { plants in } \\
\text { bloom }\end{array}$ & $\begin{array}{l}\text { All } 10 \text { plants in } \\
\text { bloom }\end{array}$ \\
\hline
\end{tabular}

1 Plants were transplanted to pots on Dec. 11 and final data taken, including harvest, on Feb. 3.

\section{SUMMARY}

Beneficial effects were secured by the application of 1-percent filter-press cake to tomato plants, shown by increases in both weight of plant and improved date of flowering. This effect increased when sterilized soil was used together with 1-percent filter-press cake, as against soil which was not sterilized + 1-percent filter-press cake.

\section{RESUMEN}

Las plantas de tomate desarrolladas en tierra y a las cuales se les aplicó 1 por ciento de cachaza resultaron superiores en peso y florecieron más que las que se desarrollaron sin cachaza. 
Este efecto sobre las plantas fue más significativo cuando se usó tierra esterilizada con 1 por ciento de cachaza, que cuando se usó tierra sin esterilizar con 1 por ciento de cachaza.

\section{LITERATURE CITED}

1. Samuels, G., and Landrau, P., Jr., Filter-press cake as fertilizer, $J$. Agr. Univ. P.R. 39(4) 198-213, 1955.

2. Riollano, A., The value of filter-press cake as a fertilizer for vegetable crops, preliminary trials with tomatoes and eucumbers, Proc. Amer. Soc. Hort. Sci. 42 547-50, 1943.

3. Landrau, P., Jr., and Samuels, G., Influence of fertilizers on the yield of the Plamar 8 variety of tomatoes on a Coto clay, J. Agr. Univ. P.R., 39(2) 77-83, 1955.

4. - The effect of fertilizers on the yield and quality of sweetpotatoes, $J$. Agr. Univ. P.R., 35(2) 71-87, 1951.

5. Bonnet, J. A., Lugo-López, M. A., and Rico-Ballester, M., Effect of incorporating organic materials into a Clay soil of Lajas Valley on the yields of food crops, J. Agr. Univ. P.R., 41(3) 173-8, 1957.

6. Hernández-Medina, E., The beneficial effect of filter-press cake on pineapple growth, development, and production: I, Effect on the plant crop, J. Agr. Univ. P.R., 36(3) 255-80, 1952.

7. - The beneficial effect of filter-press cake on pineapple growth, development, and production: II, Effect on the ratoon crop, J. Agr. Univ. P.R., 36(3) 281$317,1952$.

8. Hernández-Medina, E., Cruz-Miret, A., and Lugo-López, M. A., Residual effect of filter-press-cake applications on pineapple yields, J. Agr. Univ. P.R., 41 (3) 197-201, 1957.

9. Lugo-López, M. A., Hernández-Medina, E., Cibes-Viadé, H., and Vicente Chandler, J., The effect of filter-press cake on the physical and chemical properties of soils, J. Agr. Univ. P.R., 37 (3) 213-23, 1953.

10. Lugo-López, M. A., Hernández-Medina, E., and Landrau, P., Jr., Differential responses of some tropical soils to additions of organic matter, $J$. Agr. Univ. P.R., 40 (1) 70-7, 1956.

11. Locsin, C. L., Filter-press cake as fertilizer, Victoria Milling Co., Inc., Victorias, Negros Occidental, Phillippines, Exp. Sta., Press Release No. 3, 1953. 